\title{
Central Bank Digital Currencies: Preliminary Legal Observations $^{\dagger}$
}

\author{
Hossein Nabilou*
}

\begin{abstract}
Breakthroughs in financial technology (fintech), ranging from early coins and banknotes to card payments, e-money, mobile payments, and more recently, cryptocurrencies portend transformative changes to the financial and monetary systems. Bitcoin (BTC) and cryptocurrencies bear a significant resemblance to base money or central bank money (CeBM). This functional similarity can potentially pose several challenges to central banks in various dimensions. It may pose risks to central banks' monopoly over issuing base money, to price stability, to the smooth operation of payment systems, to the conduct of monetary policy, and to the stability of credit institutions and the financial system. From among several potential policy responses, central banks have been investigating and experimenting with issuing central bank digital currency (CBDC). This paper investigates CBDC from a legal perspective and sheds lights on the legal challenges of introducing CBDC in the euro area. Having studied the potential impact of issuing CBDC by the European Central Bank (ECB), particularly on the banking and financial stability, on the efficient allocation of resources (i.e., credit), as well as on the conduct of monetary policy, the paper concludes that issuing CBDC by the ECB would face a set of legal challenges that need to be resolved before its launch at the euro area level. Resolving such legal challenges may prove to be an arduous task as it may ultimately need amendments to the Treaty on the Functioning of the European Union (TFEU).
\end{abstract}

Keywords: Central bank digital currency, Central bank, European Central Bank, Cryptocurrency, Bitcoin, Money JEL classification: $E 42, E 51, E 58, G 01, G 23, G 28, K 22, K 23, K 24$

\footnotetext{
$\dagger$ The author is grateful to Prof. André Prüm for his insights, comments and feedback on the earlier drafts of this paper. All errors are those of the author.

* University of Luxembourg; Faculty of Law, Economics and Finance; LL.M., University of Pennsylvania Law School; E-mail: hossein.nabilou@uni.lu
} 


\section{Introduction}

The history of money has been a battlefield between governments and the private sector. ${ }^{1}$ Historical examples of government reactions to privately issued money - eventually culminating in banning or otherwise controlling private money by governments ${ }^{2}$ - underline the importance of money as a coordination device for facilitating transactions in human societies by taking up the role of a unit for the uniform measurement of value across several goods and services. In modern times, when governments appeared to have conclusively won the battle over the creation of base money, ${ }^{3}$ the rise of cryptocurrencies has proved that the war is still ongoing.

Similar to the majority of financial innovations, which aim to reduce the frictions in the financial system, cryptocurrencies have emerged to address the existing market frictions stemming from the lack of a global uncensorable peer-to-peer (P2P) digital store of value and payment mechanism. One of the major challenges to the emergence of such a mechanism has been the double-spending problem. Prior to bitcoin, addressing this problem was delegated to trusted third parties in charge of centralized ledgers. ${ }^{4}$ Bitcoin solved the double-spending problem in a highly secure, ${ }^{5}$ decentralized, consensus-based ${ }^{6}$ and censorship-resistant manner. ${ }^{7}$ By doing so, Bitcoin has also created an incentive-compatible ecosystem for the security and maintenance of the Bitcoin network leading to the creation of a decentralized medium of exchange. The digital nature, a high level of security based on a Proof-of-Work (PoW) algorithm, ${ }^{8}$ properties such as no

\footnotetext{
${ }^{1}$ It seems that China was the first country that introduced fiat money and the concept of the legal tender. Prior to the fiat money, the history of paper money goes back to more than 2,000 years ago in China, where the bills of exchange (used as money) were known as ‘flying money'. See Eswar S Prasad, Gaining Currency: The Rise of the Renminbi (New York: Oxford University Press, 2017)., Chapter 1.; Charles P. Kindleberger and Robert Z. Aliber, Manias, Panics, and Crashes: A History of Financial Crises, 5 ed. (Hoboken, New Jersey: John Wiley \& Sons, Inc., 2005), 75-76. See also: David Wolman, The End of Money: Counterfeiters, Preachers, Techies, Dreamers--and the Coming Cashless Society (Boston, MA: Da Capo Press, 2012). There has also been periods during which private bank notes coexisted alongside the government-issued banknotes. See for example: Warren E. Weber, "Government and Private E-Money-Like Systems: Federal Reserve Notes and National Bank Notes," Bank of Canada Working Paper 2015-18 (2015).

${ }^{2}$ George A Selgin, Good Money: Birmingham Button Makers, the Royal Mint, and the Beginnings of Modern Coinage, $1775-1821$ (University of Michigan Press, 2011), 12-13. (especially chapter VI, explaining how private coinage become outlawed). See also: Lawrence H. White, "Competing Money Supplies," The Library of Economics and Liberty (2018).

${ }^{3}$ Base money or high-powered money is the money issued by central banks and in most economies consists of banknotes and coins, as well as demand/sight deposits held by commercial banks at the central bank.

${ }^{4}$ For an overview of early attempts to solve this problem, see: Arvind Narayanan and Jeremy Clark, "Bitcoin's Academic Pedigree," Communications of the ACM 60, no. 12 (2017).; Aaron van Wirdum, "The Genesis Files: If Bitcoin Had a First Draft, Wei Dai's B-Money Was It," Bitcoin Magazine (15 June 2018).; Aaron van Wirdum, "The Genesis Files: How David Chaum's Ecash Spawned a Cypherpunk Dream," Bitcoin Magazine (24 April 2018).; Aaron van Wirdum, "The Genesis Files: Hashcash or How Adam Back Designed Bitcoin's Motor Block," ibid. (4 June 2018).;

5 Thus far, Bitcoin has proved to be one of the most secure financial networks. Other blockchain-based cryptocurrencies may prove less secure. For example, more recently, there has been a few successful $51 \%$ attacks to perform double-spend attacks on some cryptocurrencies such as Verge, Bitcoin Gold, MonaCoin and more recently on Ethereum Classic. See: Cali Haan, "Verge, Bitcoin Gold and Monacoin Hacked," Crowdfund InsiderMay 25, 2018.

${ }^{6}$ Bitcoin itself can be viewed as an invention that emerged to overcome social scalability problem in the first place. Although most discussions about scalability is limited to technological scalability, the problem of social scalability stands at the core of the scalability issues in bitcoin. Indeed, the perceived inefficiencies in the PoW algorithm can be understood in the balance struck between social scalability and computational scalability, which in the Bitcoin Blockchain the latter is sacrificed to improve the former. For more details, see: Nick Szabo, "Money, Blockchains, and Social Scalability," Unenumerated (February 09, 2017).

${ }^{7}$ Satoshi Nakamoto, "Bitcoin: A Peer-to-Peer Electronic Cash System," (2008).

${ }^{8}$ For a demonstration of the potential problems of the Bitcoin protocol and its implications for its long-term security, see: Raphael Auer, "Beyond the Doomsday Economics of "Proof-of-Work" in Cryptocurrencies," BIS Working Papers No 765 (2019).
} 
double-spend, ${ }^{9}$ forge-proof, tamper resistance, censorship resistance, pseudonymity (and anonymity), cheaper transaction costs, ${ }^{10}$ and decentralized, distributed trust feature of bitcoin all contribute to its uniqueness. $^{11}$

Such features coupled with cryptocurrencies' hybrid nature, which allows them to be used as a means of payment, ${ }^{12}$ investment, ${ }^{13}$ and access, ${ }^{14}$ and the new forms of risks to which they have given rise, have attracted regulatory attention ranging from financial crime enforcement agencies ${ }^{15}$ to banking, securities, and commodity markets regulators. ${ }^{16}$ With the increasing popularity of cryptocurrency, they may pose specific challenges to the financial and monetary systems that can directly or indirectly involve central banks both in their monetary policy capacity and supervisory capacity. This has already been pronounced in the recent concerns about parasitic relationships between cryptocurrencies and central bank money (CeBM), and concerns about the level playing field raised by the Bank for International Settlements (BIS). ${ }^{17}$ Some of these challenges would pose threats to the activities, financial market infrastructures (FMIs) and entities that fall within the European Central Bank's (ECB) and European System of Central Banks' (ESCB) scope of activities, legal powers, and competence. These challenges include potential threats to price stability, to the smooth operation of payment systems, to the implementation of monetary policy, to the prudential supervision of credit institutions, to the stability of the financial system, and to ECB's exclusive right to issue base money. ${ }^{18}$

\footnotetext{
${ }^{9}$ Although there have been instances of double spend on the bitcoin blockchain, such instances have remained extremely rare. See: BitMEX Research, "A Complete History of Bitcoin's Consensus Forks," (28 December 2017).

${ }^{10}$ Although at some point, transaction cost of bitcoin transactions soared, it came down eventually. It seems that new developments, such as transaction batching, and second-layer solutions, such as the Lightning Network, are substantially reducing transaction costs. See: Joseph Poon and Thaddeus Dryja, "The Bitcoin Lightning Network: Scalable Off-Chain Instant Payments," (2016). 11 Andreas M. Antonopoulos, Mastering Bitcoin: Programming the Open Blockchain (Sebastopol, CA: O'Reilly Media, Inc.,, 2017), 275-78.

12 Primarily known as 'cryptocurrencies'

13 Also known as 'security tokens'

14 Also known as 'utility tokens'. Cryptoassets could be classified as digital commodities (cryptocommodities) representing raw digital resources, or digital tokens (cryptotokens) representing finished digital goods and services. See: Chris Burniske and Jack Tatar, Cryptoassets: The Innovative Investor's Guide to Bitcoin and Beyond (New York: McGraw Hill, 2018). Chapter 4. Some of these assets can potentially become a new asset class with potential of maturing into a valuable portfolio diversification instrument. Aleksander Berentsen and Fabian Schär, "A Short Introduction to the World of Cryptocurrencies," Federal Reserve Bank of St. Louis Review 100, no. 1 (First Quarter 2018). https://doi.org/https://doi.org/10.20955/r.2018.1-16.

15 For an overview of regulatory challenges of originating from the rise of distributed ledger technology, fintech and cryptocurrencies, see: Peter Yeoh, "Regulatory Issues in Blockchain Technology," Journal of Financial Regulation and Compliance 25, no. 2 (2017). https://doi.org/doi:10.1108/JFRC-08-2016-0068.; Phoebus Athanassiou, "Impact of Digital Innovation on the Processing of Electronic Payments and Contracting: An Overview of Legal Risks," ECB Legal Working Paper Series No 16 (October 2017).; European Central Bank, "The Potential Impact of Dlts on Securities Post-Trading Harmonisation and on the Wider Eu Financial Market Integration," (Frankfurt am MainSeptember 2017).; European Securities and Markets Authority, "The Distributed Ledger Technology Applied to Securities Markets," (Paris: European Securities and Markets Authority, 2017).

16 Authority, "The Distributed Ledger Technology Applied to Securities Markets."; European Central Bank, "Virtual Currency Schemes," (Frankfurt an Main: European Central Bank, October 2012).; European Central Bank, "Virtual Currency Schemes- a Further Analysis," (February 2015 2015).

${ }^{17}$ Agustín Carstens, "Money in the Digital Age: What Role for Central Banks?," (House of Finance, Goethe University, Frankfurt: Bank for International Settlements, February 6, 2018).

${ }^{18}$ For a detailed study of such effects on central banking, see: Hossein Nabilou and André Prüm, "Central Banks and Regulation of Cryptocurrencies," (2019).
} 
Regulators can take different approaches to addressing the threats of cryptocurrencies. They may involve in regulating the code or protocol (i.e., design-based regulation), ${ }^{19}$ developers, ${ }^{20}$ the design features of a given blockchain, node operators, wallet providers, ${ }^{21}$ miners, and users, or imposing rules and standards for governing white papers. In addition, they may consider regulating exchanges - where cryptocurrencies are exchanged for fiat money - custodians (including custodian wallet providers) and other service providers, such as merchant acceptance facilities. There are also certain regulatory, supervisory and oversight tools at the ECB's disposal through which it can directly or indirectly influence cryptocurrency markets. However, this paper focuses on one policy response to the potential threats of cryptocurrencies, i.e., issuing central bank digital currency (CBDC). The merits of issuing $\mathrm{CBDC}$ has been studied from an economic perspective, ${ }^{22}$ however, legal treatment of issuing CBDC remains under-investigated. ${ }^{23}$ This paper is an attempt to narrow this gap.

The paper proceeds as follows. After a brief introduction to bitcoin and its relation to CeBM, the paper explores the legal basis for introducing CBDC by the ECB. Then, it focuses on the legal obstacles to issuing CBDC by studying the potential effects of CBDC on banking and financial stability, on the efficient allocation of financial resources, and on the conduct of monetary policy by central banks, which could have broader societal implications far beyond central banking. The paper concludes that, depending on the design features of a specific CBDC, its issuance might require introducing additional legal and judicial safeguards and might ultimately require amendments to the Treaty on the Functioning of the European Union (TFEU). As the road to introducing CBDCs at the euro-area level could be fraught with several legal obstacles and uncertainties, central banks can best mitigate the potential negative impact of cryptocurrencies by taking a proactive role in reducing the existing frictions in payment systems.

\footnotetext{
${ }^{19}$ For the concept of design-based regulation and examples thereof, see: Lawrence Lessig, Code: And Other Laws of Cyberspace (New York: Basic Books, 1999).; Lawrence Lessig, Code: Version 2.0 (New York: Basic Books, 2006).; Primavera De Filippi and Aaron Wright, Blockchain and the Law: The Rule of Code (Cambridge, Massachusetts: Harvard University Press, 2018).; ; Lawrence Lessig, "The New Chicago School," The Journal of Legal Studies 27, no. S2 (1998). Although regulating the code itself may often face the obstacle of technological neutrality requirement.

${ }^{20}$ For an argument against regulating developers, see: Aaron van Wirdum, "A Primer on Bitcoin Governance, or Why Developers Aren't in Charge of the Protocol," BITCOINMAGAZINESept. 7, 2016.; See also: Jerry Brito and Peter van Valkenburgh, "Writing and Publishing Code Alone Cannot Be a Crime," CoinCenter.org (Octover 29, 2018).

${ }^{21}$ Such wallet providers could be regulated as Money Service Businesses (MSBs) requiring money transmitter license, or money remittance service providers, both of which are equivalent to payment institutions in the EU.

22 John Barrdear and Michael Kumhof, "The Macroeconomics of Central Bank Issued Digital Currencies," Bank of England Staff Working Paper No. 605 (2016).; ibid.

${ }^{23}$ For a study exploring legal aspects of CBDC, see: Phoebus L. Athanassiou, Digital Innovation in Financial Services: Legal Challenges and Regulatory Policy Issues (Alphen aan den Rijn: Kluwer Law International B.V., 2018), Chapter 7.
} 


\section{Bitcoin, base money and central banking}

In modern economies, money takes different forms and is issued by various institutions. In this sense, the ECB's "exclusive right to authorise the issue of euro banknotes within the Union" ${ }^{24}$ does not mean that issuing money is the sole prerogative of central banks. Indeed, commercial banks had been creating money long before the advent of modern central banking. ${ }^{25}$ Recent evidence from the UK suggests that banks create and allocate approximately $97 \%$ of the money supply. ${ }^{26}$ In addition to CeBM and commercial bank money (CoBM), which consist of privately issued bank liabilities that promises to pay CeBM on demand, shadow banking quasi-money in the form of securities (promises to pay currency or deposits during a certain period of time in the future) can be viewed as an additional form of institutional money. ${ }^{27}$

Central banks often view competition in the provision of currencies somewhat healthy for the economy, in that multiple issuers of money can help enhance innovation and efficiency in the provision of payment and other financial services. ${ }^{28}$ For example, in ECB's view, neither mono-banking (central bank as the only issuer of money) nor free banking (commercial banks as the sole money suppliers) are sufficiently stable or efficient, and coexistence of CeBM and CoBM should be preserved. ${ }^{29}$ However, there are significant differences between CoBM, shadow banking money, e-money ${ }^{30}$ and cryptocurrencies that would warrant a different approach by central banks towards cryptocurrencies.

\footnotetext{
${ }^{24}$ Art. 128(1) Treaty on the Functioning of the European Union (TFEU), and Article 16 of the Protocol (no 4) on the Statute of the European System of Central Banks and of the European Central Bank (hereinafter ESCB/ECB Statute).

${ }^{25}$ See Prasad, Gaining Currency: The Rise of the Renminbi, Chapter 1.; Kindleberger and Aliber, Manias, Panics, and Crashes: A History of Financial Crises, 75-76. See also: Charles A. E. Goodhart, "The Two Concepts of Money: Implications for the Analysis of Optimal Currency Areas," European Journal of Political Economy 14, no. 3 (1998/08/01/ 1998): 418. https://doi.org/https://doi.org/10.1016/S0176-2680(98)00015-9. Only in contemporary history has the state had the monopoly over issuing banknotes (legal tender). For example, the first Legal Tender Act in the U.S. was passed in February 1862 authorizing the issuance of notes (greenbacks) which were "lawful money and legal tender in payment of all debts, public and private within the United States". This act was part of the government efforts to finance the civil war. It seems that until 1862, the issuance of banknotes was mainly a private enterprise in the US, a historical episode sometimes dubbed 'free banking era'.

Alternatives to standard monopoly on the issuance of notes by the central bank is minimal competition (central bank issued notes with commercial bank issued notes backed by the central bank notes on a one to one basis, e.g., of Scotland and Northern Ireland, where bank-issued notes are allowed, but backed by the Bank of England notes, currency boards and real competition (free banking). See Rosa María Lastra, "Central Banking Law," in International Financial and Monetary Law, ed. Rosa María Lastra (New York: Oxford University Press, 2015), 33-34.

${ }_{26}$ Michael; McLeay, Amar Radia, and Ryland Thomas, "Money in the Modern Economy: An Introduction," Bank of England Quarterly Bulletin 2014 Q1 (2014 Q1).; Michael; McLeay, Amar; Radia, and Ryland Thomas, "Money Creation in the Modern Economy," ibid. (;

27 Perry Mehrling, "The Inherent Hierarchy of Money," Social Fairness and Economics: economic essays in the spirit of Duncan Foley 169 (2012).; See also: Zoltan Pozsar, "Shadow Banking: The Money View," Office of Financial Research Working Paper (July 02, 2014 2014).

${ }^{28}$ European Central Bank, The Payment System: Payments, Securities and Derivatives, and the Role of the Eurosystem (Frankfurt am Main: European Central Bank, 2010), 45.

29 Ibid.

30 The E-money directive (EMD) defines electronic money as "electronically, including magnetically, stored monetary value as represented by a claim on the issuer which is issued on receipt of funds for the purpose of making payment transactions ..., and which is accepted by a natural or legal person other than the electronic money issuer". Directive 2009/110/EC of the European Parliament and of the Council of 16 September 2009 on the taking up, pursuit and prudential supervision of the business of electronic money institutions amending Directives 2005/60/EC and 2006/48/EC and repealing Directive 2000/46/EC, OJ L 267, 10.10.2009, p. 7-17. (e-money directive) As bitcoin is not a claim on anybody, classification of bitcoin as e-money would be a mistake.
} 
To understand the unique properties of bitcoin as compared to traditional CeBM, CoBM, shadow banking quasi-money, and e-money, it is important to analyze it along three dimensions of representation (virtual v. physical), transaction handling (centralized v. decentralized), and money creation (monopolistic v. competitive). ${ }^{31}$ Seen through this lens, bitcoin is the only currency that is virtual in representation, decentralized in transaction handling (in the sense that final clearing and settlements are conducted in a decentralized fashion using a native token), and competitive in money creation. These properties bestow a unique status upon bitcoin among cash, commodity money (gold), CoBM, ${ }^{32}$ shadow banking quasi-money, e-money and proposed CBDC or Digital Base Money (DBM).

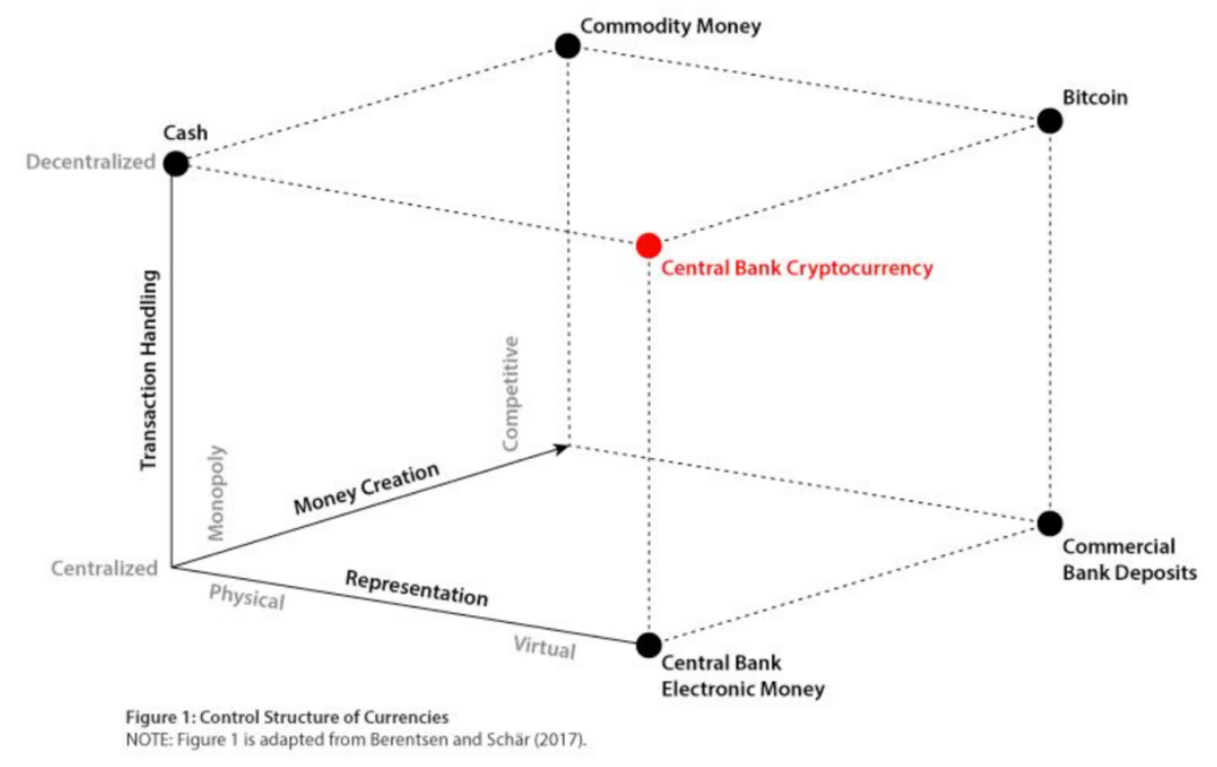

Source: Berentsen \& Schar (2018)

For the purposes of this paper, special emphasis should be placed on the transaction handling aspect of bitcoin. Although CoBM is issued by commercial banks, which are predominantly licensed or supervised by central banks and enjoy the protection of deposit insurance funds, its value and convertibility are being put to the test on a daily basis as the CeBM is used as the ultimate settlement asset in wholesale payment systems. ${ }^{33}$ In other words, despite its designation as privately issued money, in effect, CoBM is tethered money - a claim against the commercial bank to pay CeBM - and can only be considered as an extension of CeBM. This equally applies to shadow banking quasi-money as well as e-money. However, cryptocurrencies do not aim to maintain a par value with any fiat currency, and it is exactly in this sense

\footnotetext{
${ }^{31}$ See: Aleksander Berentsen and Fabian Schar, "The Case for Central Bank Electronic Money and the Non-Case for Central Bank Cryptocurrencies," Federal Reserve Bank of St. Louis Review (2018).

32 Although CoBM is not a legal tender, it is predominantly used as a medium of exchange.

${ }^{33}$ Bank, The Payment System: Payments, Securities and Derivatives, and the Role of the Eurosystem, 45.
} 
that cryptocurrencies are essentially different from $\mathrm{CoBM}$ and other types of private money. In other words, the daily convertibility of CoBM to CeBM entails that CoBM does not attempt to become a unit of account and a separate parallel currency and directly compete with CeBM, but cryptocurrencies do.

It is also worth noting that a cryptocurrency, such as bitcoin, is an unanchored or untethered medium of exchange, and under the current legal regime for payments in Europe, it is neither $\mathrm{CoBM}^{34}$ nor shadow banking quasi-money. It cannot be viewed as e-money either. ${ }^{35}$ To the contrary, since bitcoin is used as the ultimate settlement asset within its own blockchain, it bears a resemblance to CeBM as the ultimate settlement asset for payments with fiat money. ${ }^{36}$

As the ECB has the monopoly on the issuance of base money in the euro area, ${ }^{37}$ potential wider adoption of cryptocurrencies by the general public and their use as the settlement asset within their own blockchains covering everyday transactions would be in direct defiance of the role of CeBM. Although the coexistence of centralized and decentralized payment systems would ensure an additional layer of redundancy and would increase the resilience of the overall payment system, ${ }^{38}$ it appears that the wider adoption of parallel currencies used as ultimate settlement assets in itself would pose threats to the credibility of the unit of account. In this context, mass adoption of cryptocurrencies has the potential to challenge the monetary sovereignty of a nation-state or a currency area (i.e., the monetary policy flexibility and independence) and governments' seigniorage revenues originating from creating money and could potentially lead to the loss of central banks' control over money supply. Needless to say, the realization of such potential threats however unlikely they may be - would justify the ECB's intervention in the cryptocurrency markets.

However, the potential and hypothetical impacts of cryptocurrencies would not warrant an immediate regulatory action, because the impact of cryptocurrencies on central banks are largely dependent on the widespread adoption of such currencies by the general public. Despite bitcoin's unique attributes and the fact that the wider adoption of parallel cryptocurrencies would make it difficult for a central bank to achieve

\footnotetext{
${ }^{34} \mathrm{CoBM}$ is sometimes known as scriptural money.

${ }^{35}$ See: European Banking Authority, "Report with Advice for the European Commission on Crypto-Assets," (9 January 2019$), 14$. In ECB's opinion of 26 April 2006 on a proposal for a directive on payment services in the internal market (ECB/2006/21) (2006/C 109/05), the ECB suggests that a definition of scriptural money should be provided. However, it specifies that only central banks and credit institutions (which include e- money institutions) may hold scriptural money. Available at: https://www.ecb.europa.eu/ecb/legal/pdf/c 10920060509en00100030.pdf

The Payment Services Directive 2 (PSD2) does not contain any definition of scriptural money. However, it seems that the term scriptural money can hardly be stretched to include cryptocurrencies.

${ }^{36}$ Hossein Nabilou and André Prüm, "Ignorance, Debt and Cryptocurrencies: The Old and the New in the Law and Economics of Concurrent Currencies," Journal of Financial Regulation (forthcoming) (2018).; Nabilou and Prüm, "Central Banks and Regulation of Cryptocurrencies."; Max Raskin and David Yermack, "Digital Currencies, Decentralized Ledgers, and the Future of Central Banking," (National Bureau of Economic Research, 2016).

37 Although CoBM can also be used as ultimate settlement asset (especially in some cross-border payments and settlements systems), most international standards as well as national regulations require the use of CeBM in the wholesale payments and settlement systems. See: Regulation of the European Central Bank (EU) No 795/2014 of 3 July 2014 on oversight requirements for systemically important payment systems (ECB/2014/28) OJ L 217, 23.7.2014, p. 16-30, Art. 10

38 Eswar Prasad, "Central Banking in a Digital Age: Stock-Taking and Preliminary Thoughts," Hutchins Center on Fiscal \& Monetary Policy at Brookings (April 2018): 14.
} 
its price stability objective, the prospect of the CeBM being replaced by bitcoin is virtually nil. ${ }^{39}$ This is mainly due to certain limitations that are embedded in the Bitcoin protocol by design. Due to the limitation on supply, unlike CeBM, bitcoin does not have inflation risk. ${ }^{40}$ However, it has compromised three important functions of a stable monetary system. First, it affords no protection against the risk of structural deflation. Second, its inflexible supply schedule would deprive policymakers of significant policy levers and remove the possibility of any flexible response to temporary shocks to the bitcoin demand and the possibility of smoothing the business cycle and minimizing macroeconomic dislocations, which is considered as one of the main functions of monetary policy. ${ }^{41}$ And finally, such limitations would effectively remove the possibility of having a lender of last resort (LOLR) ${ }^{42}$ Consequently, in its current form, price stability under the bitcoin standard would be hard to achieve. ${ }^{43}$ These limitations put specific constraints on bitcoin's promise of becoming a unit of account, which aims to replace $\mathrm{CeBM},{ }^{44}$ and discourage bitcoin adoption at the nation-state or the currency-area level. That being said, it is not entirely impossible to conceive a scenario where a widely accepted cryptocurrency would become a parallel or concurrent currency exerting competitive pressure on CeBM. ${ }^{45}$

\section{Central banks' policy responses}

In such an unlikely scenario, despite the existence of a panoply of various regulatory strategies, the ECB would have very few options to regulate cryptocurrencies due to its limited mandate, the scope of competence and tools to achieve its objectives. ${ }^{46}$ Despite such limitations, there seem to be two main tools by which the ECB can directly influence the cryptocurrency markets. One such tool appears to be through its collateral eligibility framework within the ECB operations. As the ECB is bound to collateralize its credit

\footnotetext{
${ }^{39}$ A virtually hard cap and inflexible supply schedule on the number of bitcoins begets price volatility in response to the demand shocks, making it a hard sell as a unit of account. The hard cap on the number of bitcoins additionally means that adoption of bitcoin by any country would put hard limits on the monetary policy and effectively remove monetary sovereignty, making bitcoin unattractive for any country to use it as a currency. Therefore, in its current form, price stability under bitcoin standard would be highly unlikely. In terms of monetary policy, bitcoin is dissimilar to CoBM, which is demand driven and very much responsive to the demands for credit. The same applies to the quasi-money created by the shadow banking system.

${ }^{40}$ Although some cryptocurrencies such as bitcoin have limits on their total number issuance, there is no limit on the cryptocurrency brands that could be issued. Currently, there are more than 2,000 different cryptocurrencies and proliferation of such currencies are likely to lead to suboptimal or unstable equilibria and affect price stability. See: Daniel R Sanches, "Bitcoin Vs. The Buck: Is Currency Competition a Good Thing?," Federal Reserve Bank of Philadelphia Economic Insights Q2 2018 (2018): 13.

${ }^{41}$ Milton Friedman, "The Role of Monetary Policy," American Economic Review 58, no. 1 (1968).

42 Dong He, "Monetary Policy in the Digital Age," Finance \& Development 55, no. 2 (June 2018).

43 George Selgin, "Synthetic Commodity Money," Journal of Financial Stability 17 (2015/04/01/ 2015): 98. https://doi.org/https://doi.org/10.1016/j.jfs.2014.07.002.

${ }^{44}$ It is also unlikely that bitcoin can become a substitute for CoBM, as the latter has its unique advantages serving various needs of a given economy.

45 Raskin and Yermack, "Digital Currencies, Decentralized Ledgers, and the Future of Central Banking." However, as the development of banking and shadow banking around bitcoin cannot be ruled out, bitcoin may in the future directly compete against commercial bank, as well as shadow banking quasi-money.

${ }^{46}$ One could imagine a hypothetical scenario where the ECB would accept to grant access to ECB liquidity for, say, certain businesses that issue stablecoins backed by the euro. As part of the access criteria to the ECB liquidity, the ECB might require the centralized scheme governance authorities of such businesses to comply with certain prudential requirements.
} 
operations,${ }^{47}$ it may refuse any cryptocurrency collateral or any asset that is linked to cryptocurrencies as collateral (i.e., eligible marketable assets). The second tool would be through the ECB's task of conducting foreign-exchange operations or holding and managing the official foreign reserves of the Member States. Under this task, the ECB may have the power to hold certain cryptocurrencies. ${ }^{48}$

However, the main venue through which the ECB can take action is through indirect channels using its regulatory, supervisory and oversight powers over banking and payment systems, which may include setting participation and access criteria to ECB's payment and settlement infrastructures for payment and banking institutions with substantial cryptocurrency activities. Within this framework, the ECB may cut access to its infrastructure for the credit and payment institutions that have material exposures to cryptocurrency exchanges or payment institutions. The second indirect channel for the regulation of cryptocurrency by the ECB is within the framework of its comprehensive assessment (asset quality review (AQR) and stress testing), through which it can establish a new framework for assessing credit institutions' exposure to cryptocurrencies.

From among the various policy options at the disposal of regulators in general and the ECB in particular, this paper only studies issuing CBDC. ${ }^{49}$ In addition to certain incremental changes that central banks can effect or catalyze, issuing CBDC or DBM is the main innovative non-regulatory action that they can take as a strategy to provide an alternative virtual currency, which could aim at complementing, substituting or otherwise exerting a competitive force on cryptocurrencies by leveraging on its price stability. ${ }^{50}$ This could offer a stable virtual currency to users and could function as a unit of account in cryptocurrency markets the lack of which currently poses one of the most challenging issues facing cryptocurrency markets.

\footnotetext{
${ }^{47}$ Article 18.1, second indent, ESCB/ECB Statute,

${ }^{48}$ As the ECB and NCBs can "acquire and sell spot and forward all types of foreign exchange assets and precious metals", (Art. 23 ESCB Statute) and as 'foreign exchange assets' include "securities and all other assets in the currency of any country or units of account and in whatever form held", (Art. 23 ESCB Statute) it would be difficult to argue that the ECB might not have the power to acquire and hold cryptocurrencies if need be. If bitcoin becomes a major currency in the future, central banks may engage in buying and intervening in the bitcoin markets under the mandate of managing their foreign reserves. As this scenario appears to be unlikely at the moment, this paper will not discuss it.

${ }^{49}$ For a definition of CBDC and its unique features as compared to CeBM, see: Athanassiou, Digital Innovation in Financial Services: Legal Challenges and Regulatory Policy Issues, 185. CBDC would be different from e-money. E-money institutions are explicitly prohibited from paying interest on the e-money, i.e., e-money is not an interest-bearing instrument. While as the proponents of eurocoins (CBDCs issued by the ECB) are currently formulating, the eurocoins would be interest-bearing financial instruments. This interest could be a negative interest rate. Indeed, one frequently quoted reason for introducing CBDC is that it removes the zero lower bound constraint and opens up the central bank's hands in monetary policy operations. In the presence of cash or cash-like financial instruments, hoarding physical coins and banknotes, paying zero interest rate, by the users if the central bank decides to impose negative interest rates effectively puts some constraints on the imposition of negative interest rates.

One of the first central banks contemplating to issue CBDC is the Sveriges Riksbank. See: Sveriges Riksbank, "The Riksbank's EKrona Project, Report 1," in E-krona reports (Stockholm: Sveriges Riksbank, September 2017).; Sveriges Riksbank, "The Riksbank's E-Krona Project Report 2," in E-krona reports (Stockholm: Sveriges Riksbank, October 2018).

50 David Andolfatto, "Fedcoin: On the Desirability of a Government Cryptocurrency," MacroMania 2018 (February 03, 2015).
} 
Indeed, the continuous controversies about the existing stablecoins ${ }^{51}$ and the mounting interest in creating various new stablecoins in cryptocurrency markets in 2018 showed the importance of price stability for an effective digital medium of exchange. However, the majority of these attempts to create stablecoins were limited to using collateralization techniques to create safety and stability, giving birth to cryptocurrencies that are either collateralized by fiat money or by cryptocurrencies. Prior financial crises, and in particular runs on repos during such crises, have demonstrated that such techniques can hardly bring long-term safety and stability. ${ }^{52}$ In the case of cryptocurrencies based on algorithmic central banking, it is hard to imagine their success in the absence of a long-established reputation of price stability. This might prove to be a window of opportunity for central banks to leverage their existing credibility to create stable CBDC.

However, from technical and economic perspectives, issuing CBDC has proved to be controversial as it carries many risks alongside its potential benefits. ${ }^{53}$ Despite the perceived benefits of issuing CBDC in term of price stability, the smooth operation of payment systems, and the conduct of monetary policy - e.g. removing the zero lower bound (ZLB) constraint on monetary policy operations - the decision to issue CBDC should be made taking a full account of a set of broader policy objectives, including technical (safety and efficiency considerations), economic and legal considerations such as technological neutrality and the users' freedom of choice of means of payments. ${ }^{54}$ In the next section, the paper studies the legal basis for introducing CBDC in the euro area followed by its potential impact on the monetary and financial system.

\section{Issuing CBDC: the legal basis}

The basic principles of public and constitutional law imply that public entities, including regulators, have limited and enumerated powers and once such entities' conducts or actions do not fall within the scope of one of those enumerated powers, they would be considered ultra vires and unconstitutional. In multilayered constitutional arrangements, such as that of the EU and the euro area, the principles of conferral,

51 See for example: Anonymous (32E3690D50B3B477DF7841212D4BB938DC9CDB50307618328E7F8B53F37CC1E2), "Quantifying the Effect of Tether," (January 24, 2018).; John M Griffin and Amin Shams, "Is Bitcoin Really Un-Tethered?," SSRN Working Paper Series (2018).

52 Gary B. Gorton and Andrew Metrick, "Securitized Banking and the Run on Repo," Journal of Financial Economics 104, no. 3 (2012).; Antoine Martin, David Skeie, and Ernst-Ludwig von Thadden, "Repo Runs," The Review of Financial Studies 27, no. 4 (2014). https://doi.org/10.1093/rfs/hht134.; Adam Copeland, Antoine Martin, and Michael Walker, "Repo Runs: Evidence from the Tri-Party Repo Market," The Journal of Finance 69, no. 6 (2014). https://doi.org/10.1111/jofi.12205.; Arvind Krishnamurthy, Stefan Nagel, and Dmitry Orlov, "Sizing up Repo," ibid. (https://doi.org/10.1111/jofi.12168.;

${ }^{53}$ For an overview of the pros and cons, various design features, as well as macroeconomic impact of issuing CBDC, see: Barrdear and Kumhof, "The Macroeconomics of Central Bank Issued Digital Currencies," 9-16.; Michael Kumhof and Clare Noone, "Central Bank Digital Currencies — Design Principles and Balance Sheet Implications," Bank of England Staff Working Paper No. 725 (2018). Athanassiou, Digital Innovation in Financial Services: Legal Challenges and Regulatory Policy Issues, Chapter 7. pp. 181213. See also: Michael D Bordo and Andrew T Levin, "Central Bank Digital Currency and the Future of Monetary Policy," (National Bureau of Economic Research, 2017).; Raskin and Yermack, "Digital Currencies, Decentralized Ledgers, and the Future of Central Banking."

${ }^{54}$ Yves Mersch, "Digital Base Money: An Assessment from the Ecb's Perspective," in Speech at the Farewell ceremony for Pentti Hakkarainen, Deputy Governor of Suomen Pankki - Finlands Bank, Helsinki (16 January 2017). It seems that at the moment most central banks are not convinced that the benefits of issuing CBDC would outweigh the costs. See: Christian Barontini and Henry Holden, "Proceeding with Caution - a Survey of Central Bank Digital Currency," BIS Papers No 101 (January 2019). 
subsidiarity, and proportionality impose additional limitations on the powers of the EU institutions, agencies, and bodies. In line with this general principle, the ECB has a clear mandate and limited regulatory, supervisory and oversight tools to accomplish the objectives of the mandate. Furthermore, the ECB's acts and omissions, other than recommendations and opinions, intended to produce legal effects vis-à-vis third parties are subject to review or interpretation by the Court of Justice of European Union (CJEU). ${ }^{55}$ Accordingly, launching CBDC by the ECB should be grounded on the European constitutional, monetary and financial laws and clear the judicial tests applicable to the ECB's regulatory, supervisory, oversight and monetary policy functions.

The legal basis for issuing CBDC by the ECB could be found in the ECB's price stability mandate, its basic tasks of the definition and implementation of monetary policy, and promotion of the smooth operation of payment systems. ${ }^{56}$ To achieve price stability objective and define and implement monetary policy, the ECB is given the exclusive right to issue banknotes and coins, which have the legal tender status within the Union. ${ }^{57}$ Although it could be argued that the exclusive right to issue banknotes and coins would include the issuance of the CBDC, which appears to be their digital manifestations, a countervailing argument would suggest to the contrary, because a CBDC does not seem to be merely an inconsequential technological upgrade to the old-age technology of issuing money. As the CBDC would be programmable money, its nature would be different from that of the physical banknotes and coins. This property of CBDC means that it can accommodate features that can potentially amount to granting additional powers to central banks, such as having higher surveillance power over transactions and imposing negative interest rates, which would otherwise be absent or limited. Therefore, from a public law perspective, the legal basis for issuing CBDC by the ECB is not as clear as it might seem at first glance.

In addition to issuing banknotes and coins, the ESCB's competence in the area of payments includes promoting the smooth operation of payment systems and ensuring their safety and efficiency. ${ }^{58}$ Within this framework, the Eurosystem has the authority both in a centralized and decentralized manner (by the ECB and National Central Banks (NCBs) respectively) to oversee retail and wholesale payment systems. ${ }^{59}$ In

\footnotetext{
${ }^{55}$ Article 263 TFEU and Article 35.1 ESCB/ECB Statute.

56 Art, 127 TFEU. The ESCB's basic tasks include defining and implementing monetary policy of the Union, conducting foreignexchange operations, holding and managing the official foreign reserves of the Member States, and promoting the smooth operation of payment systems. Art. 127(2) TFEU and article 3 ESCB/ECB Statute. For this classification, see also: Lastra, "The Law of the European Central Bank," 255.

${ }^{57}$ Art. 128(1) of the TFEU and Article 16 ESCB/ECB Statute. See also: Council Regulation (EC) No 974/98 of 3 May 1998 on the introduction of the euro, OJ L 139, 11.5.1998, p. 1-5 and Council Regulation (EC) No 1103/97 of 17 June 1997 on certain provisions relating to the introduction of the euro. In particular Art. 11 of the Regulation 974/98. See also: Charles Proctor, Mann on the Legal Aspect of Money, 7 ed. (Oxford: Oxford University Press, 2012).; Helmut Siekmann, "Exit, Exclusion, and Parallel Currencies in the Euro Area," Institute for Monetary and Financial Stability Working Paper Series No. 99 (2015) (2015): 13. Lastra, "Central Banking Law," 31, 34. See also: Charles Goodhart, The Evolution of Central Banks (Cambridge, Massachusetts: The MIT Press, 1991).

${ }^{58}$ Art. 127(2) TFEU. See also: Bank, The Payment System: Payments, Securities and Derivatives, and the Role of the Eurosystem, 309.

${ }_{59}$ European Central Bank, "Revised Oversight Framework for Retail Payment Systems," (Frankfurt am MainFebruary 2016$), 7$.
} 
addition to its role as the promoter of the smooth operation of payment systems, ECB's role includes the provision of payment facilities. ${ }^{60}$ Accordingly, the ECB is the owner and operator of the wholesale payment systems using CeBM as its settlement asset. It could be argued that the ECB's task to provide facilities "to ensure efficient and sound clearing and payment systems within the Union and with other countries", ${ }^{61}$ may entail that the ECB can issue CBDC. Furthermore, the ECB can be a catalyst for change in that by promoting and encouraging sound technological and legal foundations for FMIs, it can contribute to the efficiency and stability of payment systems. ${ }^{62}$ Therefore, it seems that the ECB's powers and scope of competence in the area of payments would provide another legal basis for the ECB to issue CBDC.

Nonetheless, despite its potential profound positive impact on the conduct of monetary policy, issuing CBDC may have certain unintended consequences. For example, it would lead to banking disintermediation, ${ }^{63}$ disrupt the efficient allocation of credit, and furnish the ECB with new de facto powers. Such economic effects would give rise to new legal concerns about the scope of competences of the ECB, which may justify additional layers of accountability and perhaps different standards of judicial review on its conduct of monetary policy, especially if the CBDC is issued for retail purposes. For example, according to article $127 \mathrm{TFEU}$, "[t]he ESCB shall act in accordance with the principle of an open market economy with free competition, favouring an efficient allocation of resources, and in compliance with the principles set out in Article 119". ${ }^{64}$ Issuing CBDC would be in contravention of this provision if it leads to a centralized allocation of credit by central banks, which would be a likely scenario in the absence of appropriate safeguards.

It is noteworthy to mention that the realization of those legal challenges would largely depend on the design features of the CBDC. In what follows, the paper briefly touches upon the various design features of CBDC and then reviews its impact on the banking and financial stability and on the efficient allocation of credit, as well as its implications for the future of central banking in terms of its accountability and independence.

\section{Design features of CBDC}

CBDC may take various forms ${ }^{65}$ and based on its specific design features, it could give rise to idiosyncratic legal challenges. For example, a CBDC could be account based or value based, ${ }^{66}$ or it can be issued only for wholesale purposes or for retail purposes. Account-based CBDC would be booked in the accounts of the third parties holding accounts with the issuing central bank and the process of its transfer (including, in

\footnotetext{
${ }^{60}$ Article 22, the ESCB/ECB Statute

${ }^{61}$ Article 22, the ESCB/ECB Statute

${ }^{62}$ Athanassiou, Digital Innovation in Financial Services: Legal Challenges and Regulatory Policy Issues, 182.

${ }^{63}$ Bordo and Levin, "Central Bank Digital Currency and the Future of Monetary Policy."

${ }^{64}$ Art. 127 TFEU \& Art. 2 ESCB/ECB Statute

${ }^{65}$ Kumhof and Noone, "Central Bank Digital Currencies — Design Principles and Balance Sheet Implications."

${ }^{66}$ Mersch, "Digital Base Money: An Assessment from the Ecb’s Perspective."
} 
particular, the legal finality) would be conducted on the books of the issuing central bank. ${ }^{67}$ Account-based CBDC would be similar to reserve balances, with the only difference that besides commercial banks, account-holders would be the wider natural and legal persons (the general public). In contrast, value-based CBDC would be in the form of digitally stored tokens or units stored in the e-wallets of holders, but its transfer would be conducted and finalized in a decentralized or P2P fashion. Similar to cash, this form of CBDC would possibly provide users with anonymity with regard to the issuing central bank. ${ }^{68}$ Additional variations in design would include whether the CBDC is intended to substitute or complement bank deposits and cash, whether the holders of CBDC would be natural or legal persons or both, whether the CBDC provides a level of anonymity, at-par convertibility, and interest accrual. ${ }^{69}$ Blockchain or distributed ledger technology (DLT) may not be used for issuing CBDC, as is the case with E-Krona project of the Riksbank. ${ }^{70}$ In any event, it seems that the main difference between CBDC and other cryptocurrencies is that, in the former, as the name suggests, there remains a level of centralization. In account-based CBDC, both legs of creation and settlement are centralized, while in value-based CBDC, only the creation and destruction of money is centralized under the control of a central bank, and the transaction settlement would be decentralized. ${ }^{71}$ Accordingly, issuing CBDC is not in line with the original vision of the invention of cryptocurrencies as neither the promise of trust minimization nor decentralization is likely to be achieved in CBDCs. In this respect, CBDCs would bear no resemblance to cryptocurrencies such as bitcoin. As such, its discussion under the rubric of cryptocurrencies would remain misleading, ${ }^{72}$ and a more appropriate term for such digital currencies would be (centralized) digital currency or cash.

Additionally, as there is already DBM in the form of commercial banks' deposits with central banks for the purposes of wholesale settlements, the need for issuing CBDC for wholesale purposes remains questionable. It might be said that the main advantage of CBDC over other cryptocurrencies lies in its price stability. However, in the absence of interoperability arrangements, such stability comes at the price of its geographic limit and its attachment to a single central bank. In addition, similar to bitcoin, in the absence

\footnotetext{
${ }^{67}$ Athanassiou, Digital Innovation in Financial Services: Legal Challenges and Regulatory Policy Issues, 187.

68 Ibid.; See also: Mersch, "Digital Base Money: An Assessment from the Ecb’s Perspective."

${ }^{69}$ Athanassiou, Digital Innovation in Financial Services: Legal Challenges and Regulatory Policy Issues, 195. Thus far, it seems that two competing models in the form of proposals on the design features of CBDC have emerged. They include CAD-coin model and Fedcoin model. CAD-coin is issued on a permissioned blockchain and is intended to be used for wholesale payment services. This coin would be fully backed by cash collateral and will function as a settlement coin to be used by designated entities on a distributed permissioned platform which is linked to a central bank Real Time Gross Settlement (RTGS) system. On the contrary, Fedcoin is a retail payment medium, issued on a permissionless ledger, while the central bank retains the sole authority to create and destroy coins. For more details, see: ibid.

70 See: Riksbank, "The Riksbank’s E-Krona Project Report 2."

${ }^{71}$ Morten Bech and Rodney Grarratt, "Central Bank Cryptocurrencies," BIS Quarterly Review (2017). In their view a central bank cryptocurrency (CBCC) is "an electronic form of central bank money that can be exchanged in a decentralised manner known as peer-to-peer, meaning that transactions occur directly between the payer and the payee without the need for a central intermediary." Ibid., 56. In other words, in central bank cryptocurrency, the money creation leg of currency still remains to be the prerogative of governments (central banks) but the settlement leg is decentralized and organized in a peer-to-peer fashion.

72 For an engaging read on the CBCC, see: JP Koning, "Fedcoin," Moneyness April 11, 2018 (October 19, 2014).
} 
of a fiat-based global currency, such as the proposed Bancor envisioned by Keynes, CBDCs would only enjoy stability in relative terms as their value will continue to float against one another in Forex markets.

The multiplicity of design features of the CBDC and the limitations of space in this article would not allow a holistic and all-encompassing analysis of its effects on price stability, monetary policy, payment systems, and banking and financial stability. The following sections, therefore, only focus on some preliminary observations on the impact of CBDC on banking and financial stability, efficient allocation of financial resources, and the monetary policy based on certain assumptions on the design features of the CBDC.

\section{Impact on banking and financial stability}

One major concern about issuing CBDC would be that it would move substantial parts of the balances in the transaction accounts of the commercial banks' customers onto the central banks' balance sheets. This is because with the introduction of $\mathrm{CBDC}$, if a commercial bank cannot compensate its customers for the extra counterparty risk inherent in CoBM, there would be no reason to hold balances with a commercial bank. ${ }^{73}$ Deprived of customer deposits, commercial banks are likely to become highly dependent on the wholesale markets with higher interest rates ${ }^{74}$ and less stable funding (short-term maturities), intensifying the maturity mismatch and liquidity problems in the banking sector. ${ }^{75}$ In addition, issuing CBDC may result in the banking sector instability, especially in times of crises, where the depositors switch deposits from their commercial bank accounts to their CBDC account with central banks, facilitating a run from bank deposits to the safety of the CBDC. ${ }^{76}$ This might not be a socially optimal outcome as it would amount to commercial banking disintermediation in normal times ${ }^{77}$ and a 'destabilizing flight to quality' in distressed times. $^{78}$

\footnotetext{
${ }^{73}$ Under certain assumptions, it is argued that issuing CBDC would increase financial inclusion. See: David Andolfatto, "Assessing the Impact of Central Bank Digital Currency on Private Banks," Federal Reserve Bank of St. Louis Working Paper 2018-026B (2018). https://doi.org/https://doi.org/10.20955/wp.2018.026.; See also: Andolfatto, "Fedcoin: On the Desirability of a Government Cryptocurrency."

${ }_{74}$ Barrdear and Kumhof, "The Macroeconomics of Central Bank Issued Digital Currencies," 9.

75 Hossein Nabilou and Alessio Pacces, "The Law and Economics of Shadow Banking," in Research Handbook on Shadow Banking: Legal and Regulatory Aspects, ed. Iris H. Chiu and Iain G. MacNeil (Cheltenham, UK: Edward Elgar Publishing Inc., 2018).

76 See: Committee on Payments and Market Infrastructures, "Central Bank Digital Currencies," (Basel, Switzerland: Bank for International Settlements, 2018), 16. It is also argued that this cannot be an obstacle for introducing CBDC. Stating that "runs on individual financial institutions, or system-wide runs from bank deposits into cash, are as feasible in a world without CBDC as in a world with CBDC, and given the advantages of CBDC in case it comes to a bank resolution, may be less likely with CBDC." See: Kumhof and Noone, "Central Bank Digital Currencies - Design Principles and Balance Sheet Implications," 35. See also: Barrdear and Kumhof, "The Macroeconomics of Central Bank Issued Digital Currencies," 14-15.

77 Warren Coats, "Free Banking in the Digital Age," Banking \& Finance Law Review (2018): 413.

${ }^{78}$ Ben Broadbent, "Central Banks and Digital Currencies," Speech at the London School of Economics (2 March 2016). See also: Yves Mersch, "Virtual or Virtueless? The Evolution of Money in the Digital Age," in Lecture at the Official Monetary and Financial Institutions Forum, London (8 February 2018). For a opposite argument, see: Andolfatto, "Assessing the Impact of Central Bank Digital Currency on Private Banks."
} 
However, such an impact is ultimately dependent on the design features of CBDC. If the design of the CBDC would entail disintermediated public access to the central bank balance sheet, ${ }^{79}$ in the absence of any other remedies, introducing CBDC would result in destabilizing consequences for the banking sector. Since the introduction of CBDC is likely to transform the banking business model, banks need to evolve in response to such developments; otherwise, it would likely put the banking stability at risk. ${ }^{80}$ Such a consequence would be inimical to the ESCB's statutory mandate of contributing to "the smooth conduct of policies pursued by the competent authorities relating to the prudential supervision of credit institutions and the stability of the financial system." ${ }^{\prime 1}$

\section{Impact on the efficient allocation of resources}

Despite the fact that credit institutions, public entities, and other market participants can have access to the ECB and NCBs' balance sheets, ${ }^{82}$ currently, aside from holding cash, the general public has only an indirect or intermediated access to the ECB's balance sheet. The introduction of CBDC would imply a disintermediated public access to the central bank balance sheet, which means that the public could open an account at the central bank directly. Such direct access to the central bank's books is not unprecedented, as the Bank of England and the Sveriges Riksbank used to allow private accounts; a practice discontinued for practical reasons. ${ }^{83}$

As this disintermediated access might cause CoBM (bank deposits) to shrink, banks' ability to make loans - at least under the fractional reserve theory of banking - would be substantially restricted. As granting credit by banks amounts to decentralized creation of money or credit in the financial system, removing such a function from the banking industry and granting direct access to the central bank balance sheet to the public may eventually lead to centralization of credit allocation under the control of central banks. This, in turn, would be detrimental to the efficient allocation of credit in the economy and would undermine "the principle of an open market economy with free competition", ${ }^{84}$ in accordance to which the ECB should act. $^{85}$

\footnotetext{
${ }^{79}$ Barrdear and Kumhof define CBDC as "a central bank granting universal, electronic, 24x7, national-currency-denominated and interest-bearing access to its balance sheet.". In this view, issuing CBDC would automatically mean direct public access to central bank balance sheet. See: Barrdear and Kumhof, "The Macroeconomics of Central Bank Issued Digital Currencies," 7. For more details on public access to the central bank balance sheet and its consequences, see: Morgan Ricks, John Crawford, and Lev Menand, "A Public Option for Bank Accounts (or Central Banking for All)," Vanderbilt Law Research Paper 18-33 (2018).; Lev Menand, John Crawford, and Morgan Ricks, "Central Banking for All: Reply to Objections," Oxford Business Law Blog (27 August 2018).; Morgan Ricks, "Money as Infrastructure," Vanderbilt Law Research Paper No. 17-63 (2018).

${ }^{80}$ Mersch, "Digital Base Money: An Assessment from the Ecb’s Perspective."

${ }^{81}$ Art. 127(5) TFEU

${ }^{82}$ Art. 17 ESCB/ECB Statute.

${ }^{83}$ Bordo and Levin, "Central Bank Digital Currency and the Future of Monetary Policy," 2.

${ }^{84}$ Article 127 of the TFEU and article 2 of the ESCB/ECB Statute

85 See: Mersch, "Virtual or Virtueless? The Evolution of Money in the Digital Age."
} 


\section{A need for increased accountability for central banks}

The recent intellectual assault on cash and the move towards cashless society adds another layer of complexity to the potential impact of issuing CBDC. ${ }^{86}$ Although a case against cash is far from settled, ${ }^{87}$ the move towards digitization seems inevitable. Thus far, cash provides the only direct access to central bank balance sheets for the general public. If the introduction of CBDC is simultaneous with abolishing cash and banning other forms of private money (such as cryptocurrencies), it would effectively remove the Zero Lower Bound (ZLB) constraint in the conduct of monetary policy. On the upside, this would furnish central banks with powerful tools for the implementation of monetary policy. However, on the downside, it would entail a de facto power of slashing bank deposits or cryptocurrency deposits with central banks. Although negative interest rates have proven to work even in the presence of cash, the existence of cash and other alternatives would create an effective lower bound and limit the depth of the negative territory a central bank can march in.

In addition, physical cash provides users with "irrevocable access to the payments system". ${ }^{88}$ As payment systems are part of the FMIs, account-based CBDC would ease revoking legal and natural persons' access to such FMIs, giving rise to potential financial inclusion concerns. Financial inclusion risks have been partly addressed in the traditional payment services by the Payment Accounts Directive (PAD), ${ }^{89}$ however, the PAD in its current form, may not be applicable to payments systems based on CBDC. In the event of introducing CBDC, it seems that this Directive needs to be amended to include access to CBDC. Otherwise, issuing CBDC would grant further censorship powers and exclusionary capacity to the state vis-à-vis individuals, especially if the introduction of an account-based CBDC would coincide with the abolition of physical cash. ${ }^{90}$

Moreover, since CBDC is likely to be programmable - meaning that various smart contracts and features could be hardwired in them - it is likely that such a currency would give rise to privacy concerns, as it may erode the privacy and anonymity of users - long held to be a feature of cash - and grant additional surveillance powers to the state.

Although the acts or omissions of the ECB, other than recommendations and opinions, intended to produce legal effects vis-à-vis third parties are subject to review or interpretation by the CJEU, ${ }^{91}$ and its decisions -

\footnotetext{
${ }^{86}$ Kenneth S Rogoff, The Curse of Cash (Princeton: Princeton University Press, 2016).

87 Yves Mersch, "Why Europe Still Needs Cash," Contribution by Yves Mersch, Member of the Executive Board of the ECB for Project Syndicate (28 April 2017).; Henk Esselink and Lola Hernández, "The Use of Cash by Households in the Euro Area," ECB Occasional Paper Series No 201 (November 2017).

88 JP Koning, "The Big Problems with Big Denomination Bills," Cato Unbound (August 7, 2018).

${ }^{89}$ Directive 2014/92/EU of the European Parliament and of the Council of 23 July 2014 on the comparability of fees related to payment accounts, payment account switching and access to payment accounts with basic features Text with EEA relevance $O J L$ 257, 28.8.2014, p. 214-246 (Payment accounts directive aka PAD)

${ }^{90}$ It seems that the proliferation of various cryptocurrencies having privacy features would mitigate concerns about privacy. Therefore, if issuing CBDC would not lead to the abolition of other cryptocurrencies or cash, it would only be complementary to other payment methods. See: Bordo and Levin, "Central Bank Digital Currency and the Future of Monetary Policy," 1-2.

${ }^{91}$ Article 263 TFEU and Article 35.1. ESCB/ECB Statute
} 
both supervisory and monetary policy decisions - have been challenged several times before the CJEU, the case law of the EU give a large margin of discretion to the ECB in its monetary policy operations. ${ }^{92}$ Therefore, it seems that the risks associated with the introduction of CBDC as well as the new powers and tools that it makes available to central banks may require higher levels of central bank accountability, appropriate safeguards, and standards of judicial scrutiny.

Physical cash is the main mechanism that facilitates the use of currencies, such as the USD and the euro, as the backup to the global monetary system. ${ }^{93}$ As these currencies are used as a store of value and a fail-safe option outside their own country of issue or currency area, issuing CBDC to replace physical cash would jeopardize these currencies' role in the global payments and monetary systems, a policy concern that should not be overlooked in the decision over issuing CBDC.

To summarize, depending on the design features of the CBDC, in addition to the technical issues, and potential transitional risks, the ECB would face legal risks in issuing such a currency. Unless appropriate safeguards are in place to protect citizens from the potential abuse of the absence of the ZBL constraint, to minimize the potentially destabilizing impact of CBDC on banking and financial stability, to allow the efficient allocation of credit in a decentralized manner, and to address the potential concerns about financial inclusion and privacy, a shadow of doubt could be cast on the attempts to introduce CBDC by the ECB.

The basic principles of constitutional law would require that assuming these new powers and tools furnished by technological innovations - by an EU institution should be either grounded in the existing primary or secondary laws or should be added to the existing powers by amendments to the existing laws. As it seems that the ECB currently lacks such tools (e.g., to impose unlimited negative interest rates), employing such technological innovations should be preceded by amendments to the TFEU granting such powers to the ESCB, and arguably providing additional constitutional safeguards and higher levels of accountability for the ECB.

As the road to issuing CBDC at the euro-area level may prove to be bumpy, before issuing CBDC, to pick up the lowest hanging fruits and minimize the potential negative consequences of the proliferation of cryptocurrencies, the ECB may consider other technical measures that can help improve the efficiency of the current payment systems by reducing the existing frictions in the payment systems. In doing so, the ECB can rely on its existing powers and tools, largely at its catalyst-for-change role or under its mandate to promote the smooth operation of payment systems to effect such incremental changes. The next section studies the potential areas for improvements in the existing payments infrastructure that can help discourage the use of various risky cryptocurrencies as a payment method.

\footnotetext{
${ }^{92}$ See for example, Case T-79/13 Alessandro Accorinti and Others v European Central Bank (ECB), (affirming that the theory of legitimate expectations does not apply to monetary policy (Paragraph 67-69).)

${ }_{93}$ Koning, "The Big Problems with Big Denomination Bills."
} 


\section{Reducing the existing payment frictions}

Frictions in payments across national boundaries and the lack of a global currency have played an important role in giving birth to some of the most prominent use-cases of cryptocurrencies, in particular, in the remittance business. Therefore, before issuing CBDC, central banks may start by improving the current payment infrastructures. For example, they can join forces with their foreign counterparts within the international financial fora, or encourage payment and banking associations, to enhance the efficiency of their existing infrastructure for international or cross-border fund transfers. ${ }^{94}$ Current improvements to the payment systems catalyzed by the ECB as well as payment associations can be considered as methods to achieve such objectives. A case in point is the SEPA Instant Credit Transfer (SCT-Inst) - launched in November 2017 - enabling instant payments in euro across Europe around the clock, 365 days a year. ${ }^{95}$ TARGET Instant Payment Settlement (TIPS), offering a real-time settlement in CeBM, which went live on November 30, 2018, is another step forward in this direction. By making such infrastructure available to banking and payment institutions, the ECB, in cooperation with its international peers and in its catalystfor-change role, can encourage the banking and payment institutions to lower the fees for international payments and enhance their efficiency.

Furthermore, widening the choice of available digital payment instruments accommodating wider features in terms of efficiency, anonymity, and security would provide another alternative for cryptocurrencies and eventually may lead to mitigation of their potential impact. The existing payment instruments, such as cash, debit and credit cards, electronic fund transfers or wire transfers (including credit transfers and direct debits), online payment platforms, and e-money offer a wide range of payment solutions. However, privacy and - to a lesser degree - security in online payments are still in short supply, despite the fact that the existence of prepaid payment cards (such as gift cards) would provide certain levels of privacy.

Since the demand for privacy in payments will not disappear by the potential obsolescence of cash, offering means of digital payments that would provide certain levels of privacy is to be continued. Otherwise, the privacy-conscious users of cash or even the mafia and gangsters would migrate to more privacy-enhancing cryptocurrencies or to developing their own IOUs, which could eventually give rise to unforeseen and unintended consequences. ${ }^{96}$ Further improvements would be achieved by reducing the amount of crosssubsidization that exists in the use of different payment instruments, the most important of which has been

\footnotetext{
94 For the public-private nature of payments law, see: Agnieszka Janczuk-Gorywoda, "Evolution of Eu Retail Payments Law," European Law Review 40, no. 6 (2015). Emphasizing the fact the private initiative has often been insufficient in pushing for improvements of efficiency in the payment system and public or government intervention (in the case in question, SEPA regulation) is often needed.

95 This development can only be indirectly associated with the ECB. The Euro Retail Payments Board (ERPB) which is chaired by the ECB, requested an action plan from the European Payments Council (EPC) who eventually launched the SCT-Inst.

96 JP Koning, "The Odd Relationship between Gangster and Central Banker," Moneyness (March 2, 2018).; See also: JP Koning, "Anonymous Digital Cash," American Institute for Economic Research 2018, no. April 26 (2018).; Although it would be hard to expect a central bank to issue a complete privacy preserving digital asset, certain levels of privacy, especially towards third parties, can be built into the CBDC.
} 
in existence in the indirect and hidden relationship between card users and cash users, where the latter crosssubsidizes the former. ${ }^{97}$ The adoption of the Multilateral Interchange Fee (MIF) Regulation ${ }^{98}$ partly alleviates this problem but falls short of eliminating it.

Nonetheless, it is important to bear in mind that the use of cryptocurrencies is not entirely driven by efficiency considerations. Censorship of payments has been a major driver of cryptocurrencies. Although censorship resistance would be frowned upon under democratic and accountable governments, such a property would still be useful for citizens living under less democratic and less accountable governments. Under those regimes, censorship resistance property of cryptocurrencies can empower citizens by providing a global uncensorable digital store of value and medium of exchange, which is independent of the whims of the unaccountable political actors.

The overuse and abuse of international payment infrastructures for political purposes and sanction regimes can also encourage the use of censorship-resistant decentralized cryptocurrencies. The recent calls for establishing international payment rails independent of the US have shown the frustration with the hegemony of a single dominant player having formal (i.e., through extraterritorial application of its laws) and informal dominance over international payment infrastructures. ${ }^{99}$ Detaching wavering winds of politics from critical (payment) infrastructures and reducing the use of payment systems for sanctions would mitigate the use of cryptocurrencies both among state actors and individuals. Even within the existing sanctions regimes, provisions can be made to make cross-border payments available for international micropayments (i.e., de minimus exception). Such an exception can mitigate the impact of sanctions on ordinary citizens of sanctioned countries and could discourage them from switching to alternative payment methods with higher risk profiles.

\footnotetext{
${ }^{97}$ As merchant costs might be higher for card payments, especially those offering a reward, to compensate those costs, merchants increase the general level of prices for all the customers that eventually leads to cross-subsidization of credit card users by cash, check, or debit cards users.

${ }^{98}$ Regulation (EU) 2015/751 of the European Parliament and of the Council of 29 April 2015 on interchange fees for card-based payment transactions

99 See: Guy Chazan, "Germany Calls for Global Payments System Free of Us," Financial Times, August 21, 2018 August 21, 2018.; Yves Mersch, "Strengthening the European Financial Industry Amid Disruptive Global Challenges," Speech by Yves Mersch, Member of the Executive Board of the ECB, at the European Institute of Financial Regulation (EIFR), Paris, 3 September 2018 (September 3, 2018).; JP Koning, "Monetary Exclusion," American Institute for Economic Research (July 26, 2018).

For the first practical steps taken at the EU level, see: European Union External Action - European External Action Service, "Implementation of the Joint Comprehensive Plan of Action: Joint Ministerial Statement," news release, September 24, 2018, September 24, 2018, https://eeas.europa.eu/headquarters/headquarters-homepage/51036/implementation-joint-comprehensiveplan-action-joint-ministerial-statement_en., For more details, see also: Esfandyar Batmanghelidj and Axel Hellman, "Europe, Iran, and Economic Sovereignty: A New Banking Architecture in Response to Us Sanctions," (2018).
} 


\section{Conclusion}

Cryptocurrencies and their impact on central banking have sparked a policy debate on how to address the potential threats of cryptocurrencies. While policymakers remain largely skeptical about the potential benefits of private cryptocurrencies, they have been actively investigating the potentials of cryptocurrencies, their underlying technology, and the venues for regulating or otherwise influencing them with the aim of minimizing their social costs in terms of externalities that they may pose to the financial system. From among the panoply of the regulatory and non-regulatory actions, studying and potentially issuing CBDC have been put on the agenda of a few central banks. Despite two nearly-failed attempts to create CBDCs in Ecuador ${ }^{100}$ and Venezuela, the idea of CBDC is too-attractive-to-ignore for central banks. This paper studied the potential legal challenges that the ECB may face in issuing its own digital currency. These legal challenges arise from the potential effects of CBDC that may undermine the ECB's mandate or its basic and ancillary tasks, including its tasks in contributing to the banking and financial stability. In addition, the EU primary and secondary laws set certain constitutional constraints on the ECB in employing its policy tools, the most relevant of which is the provision that requires the ESCB to act "in accordance with the principle of an open market economy with free competition, favouring an efficient allocation of resources..." 101 Such constitutional constraints would be breached if issuing an account-based CBDC would lead to banking disintermediation as it would put central banks in the position to allocate scarce financial recourses (i.e., credit), which would - by assumption - be inefficient and against the principle of an open market economy. In addition, since CBDC is likely to be programmable money capable of accommodating various features and smart contracts, its launch would not only give rise to concerns about users' privacy but also enable central banks to impose negative interest rates by slashing users' CBDC deposited with central banks. This may justify higher levels of central bank public accountability, appropriate safeguards, and standards of judicial scrutiny.

Although the nature of the legal challenges of introducing CBDC will ultimately depend on its design features (e.g., value-based v. account-based, wholesale v. retail-oriented, interest-bearing v. non-interest bearing), the paper highlighted some of the challenges based on certain specific assumptions and argued that regardless of the economic and financial impact of issuing CBDC, which might be addressed by tinkering with various design features of a given CBDC, issuing such currencies at the euro-area level might face constitutional and legal hurdles and may eventually require amendments to the TFEU.

\footnotetext{
${ }^{100}$ Larry White, "The World's First Central Bank Electronic Money Has Come - and Gone: Ecuador, 2014-2018," Alt-M: Ideas for an Alternative Monetary Future (March 29, 2018).

${ }^{101}$ Art. 127(1) TFEU.
} 


\section{Bibliography}

Andolfatto, David. "Assessing the Impact of Central Bank Digital Currency on Private Banks." Federal Reserve Bank of St. Louis Working Paper 2018-026B (2018).

. "Fedcoin: On the Desirability of a Government Cryptocurrency." MacroMania 2018 (February $03,2015)$.

Anonymous (32E3690D50B3B477DF7841212D4BB938DC9CDB50307618328E7F8B53F37CC1E2), "Quantifying the Effect of Tether." January 24, 2018.

Antonopoulos, Andreas M. Mastering Bitcoin: Programming the Open Blockchain. Sebastopol, CA: O’Reilly Media, Inc., 2017.

Athanassiou, Phoebus. "Impact of Digital Innovation on the Processing of Electronic Payments and Contracting: An Overview of Legal Risks." ECB Legal Working Paper Series No 16 (October 2017).

Athanassiou, Phoebus L. Digital Innovation in Financial Services: Legal Challenges and Regulatory Policy Issues. Alphen aan den Rijn: Kluwer Law International B.V., 2018.

Auer, Raphael. "Beyond the Doomsday Economics of "Proof-of-Work" in Cryptocurrencies." BIS Working Papers No 765 (2019).

Barontini, Christian, and Henry Holden. "Proceeding with Caution - a Survey of Central Bank Digital Currency." BIS Papers No 101 (January 2019).

Barrdear, John, and Michael Kumhof. "The Macroeconomics of Central Bank Issued Digital Currencies." Bank of England Staff Working Paper No. 605 (2016).

Batmanghelidj, Esfandyar, and Axel Hellman. "Europe, Iran, and Economic Sovereignty: A New Banking Architecture in Response to Us Sanctions." 2018.

Bech, Morten, and Rodney Grarratt. "Central Bank Cryptocurrencies." BIS Quarterly Review (2017).

Berentsen, Aleksander, and Fabian Schar. "The Case for Central Bank Electronic Money and the NonCase for Central Bank Cryptocurrencies." Federal Reserve Bank of St. Louis Review (2018).

Berentsen, Aleksander, and Fabian Schär. "A Short Introduction to the World of Cryptocurrencies." Federal Reserve Bank of St. Louis Review 100, no. 1 (First Quarter 2018): 1-16.

Bordo, Michael D, and Andrew T Levin. "Central Bank Digital Currency and the Future of Monetary Policy." National Bureau of Economic Research, 2017.

Brito, Jerry, and Peter van Valkenburgh. "Writing and Publishing Code Alone Cannot Be a Crime." CoinCenter.org (Octover 29, 2018).

Broadbent, Ben. "Central Banks and Digital Currencies." Speech at the London School of Economics (2 March 2016).

Burniske, Chris, and Jack Tatar. Cryptoassets: The Innovative Investor's Guide to Bitcoin and Beyond. New York: McGraw Hill, 2018.

Carstens, Agustín "Money in the Digital Age: What Role for Central Banks?". House of Finance, Goethe University, Frankfurt: Bank for International Settlements, February 6, 2018.

Chazan, Guy. "Germany Calls for Global Payments System Free of Us." Financial Times, August 21, 2018 August 21, 2018.

Coats, Warren. "Free Banking in the Digital Age." Banking \& Finance Law Review (2018).

Copeland, Adam, Antoine Martin, and Michael Walker. "Repo Runs: Evidence from the Tri-Party Repo Market." The Journal of Finance 69, no. 6 (2014): 2343-80.

De Filippi, Primavera, and Aaron Wright. Blockchain and the Law: The Rule of Code. Cambridge, Massachusetts: Harvard University Press, 2018.

Esselink, Henk, and Lola Hernández. "The Use of Cash by Households in the Euro Area." ECB Occasional Paper Series No 201 (November 2017).

European Banking Authority. "Report with Advice for the European Commission on Crypto-Assets." 9 January 2019.

European Central Bank. The Payment System: Payments, Securities and Derivatives, and the Role of the Eurosystem. Frankfurt am Main: European Central Bank, 2010. 
"The Potential Impact of Dlts on Securities Post-Trading Harmonisation and on the Wider Eu Financial Market Integration." Frankfurt am Main, September 2017.

. "Revised Oversight Framework for Retail Payment Systems." Frankfurt am Main, February 2016.

" "Virtual Currency Schemes." Frankfurt an Main: European Central Bank, October 2012.

. "Virtual Currency Schemes- a Further Analysis." (February 2015 2015).

European Union External Action - European External Action Service. "Implementation of the Joint Comprehensive Plan of Action: Joint Ministerial Statement." news release, September 24, 2018, https://eeas.europa.eu/headquarters/headquarters-homepage/51036/implementation-jointcomprehensive-plan-action-joint-ministerial-statement en.

European Securities and Markets Authority. "The Distributed Ledger Technology Applied to Securities Markets." Paris: European Securities and Markets Authority, 2017.

Friedman, Milton. "The Role of Monetary Policy." American Economic Review 58, no. 1 (1968): 1-17.

Goodhart, Charles. The Evolution of Central Banks. Cambridge, Massachusetts: The MIT Press, 1991.

Goodhart, Charles A. E. "The Two Concepts of Money: Implications for the Analysis of Optimal Currency Areas." European Journal of Political Economy 14, no. 3 (1998/08/01/ 1998): 407-32.

Gorton, Gary B., and Andrew Metrick. "Securitized Banking and the Run on Repo." Journal of Financial Economics 104, no. 3 (2012): 425-51.

Griffin, John M, and Amin Shams. "Is Bitcoin Really Un-Tethered?". SSRN Working Paper Series (2018).

Haan, Cali. "Verge, Bitcoin Gold and Monacoin Hacked." Crowdfund Insider, May 25, 2018.

He, Dong. "Monetary Policy in the Digital Age." Finance \& Development 55, no. 2 (June 2018): 13-16.

Infrastructures, Committee on Payments and Market. "Central Bank Digital Currencies." Basel, Switzerland: Bank for International Settlements, 2018.

Janczuk-Gorywoda, Agnieszka. "Evolution of Eu Retail Payments Law." European Law Review 40, no. 6 (2015).

Kindleberger, Charles P., and Robert Z. Aliber. Manias, Panics, and Crashes: A History of Financial Crises. 5 ed. Hoboken, New Jersey: John Wiley \& Sons, Inc., 2005.

Koning, JP. "Anonymous Digital Cash." American Institute for Economic Research 2018, no. April 26 (2018).

"The Big Problems with Big Denomination Bills." Cato Unbound (August 7, 2018).

"Fedcoin." Moneyness April 11, 2018 (October 19, 2014).

"Monetary Exclusion." American Institute for Economic Research (July 26, 2018).

. "The Odd Relationship between Gangster and Central Banker." Moneyness (March 2, 2018).

Krishnamurthy, Arvind, Stefan Nagel, and Dmitry Orlov. "Sizing up Repo." The Journal of Finance 69, no. 6 (2014): 2381-417.

Kumhof, Michael, and Clare Noone. "Central Bank Digital Currencies — Design Principles and Balance Sheet Implications." Bank of England Staff Working Paper No. 725 (2018).

Lastra, Rosa María. "Central Banking Law." Chap. 2 In International Financial and Monetary Law, edited by Rosa María Lastra, 29-110. New York: Oxford University Press, 2015.

"The Law of the European Central Bank." Chap. 7 In International Financial and Monetary Law, edited by Rosa María Lastra, 247-85. New York: Oxford University Press, 2015.

Lessig, Lawrence. Code: And Other Laws of Cyberspace. New York: Basic Books, 1999.

Code: Version 2.0. New York: Basic Books, 2006. . "The New Chicago School." The Journal of Legal Studies 27, no. S2 (1998): 661-91.

Martin, Antoine, David Skeie, and Ernst-Ludwig von Thadden. "Repo Runs." The Review of Financial Studies 27, no. 4 (2014): 957-89.

McLeay, Michael; , Amar; Radia, and Ryland Thomas. "Money Creation in the Modern Economy." Bank of England Quarterly Bulletin 2014 Q1 (2014 Q1): 14-27.

McLeay, Michael; Amar Radia, and Ryland Thomas. "Money in the Modern Economy: An Introduction." Bank of England Quarterly Bulletin 2014 Q1 (2014 Q1): 4-13.

Mehrling, Perry. "The Inherent Hierarchy of Money." Social Fairness and Economics: economic essays in the spirit of Duncan Foley 169 (2012): 394. 
Menand, Lev, John Crawford, and Morgan Ricks. "Central Banking for All: Reply to Objections." Oxford Business Law Blog (27 August 2018).

Mersch, Yves. "Digital Base Money: An Assessment from the Ecb's Perspective." In Speech at the Farewell ceremony for Pentti Hakkarainen, Deputy Governor of Suomen Pankki-Finlands Bank, Helsinki, 16 January 2017.

. "Strengthening the European Financial Industry Amid Disruptive Global Challenges." Speech by Yves Mersch, Member of the Executive Board of the ECB, at the European Institute of Financial Regulation (EIFR), Paris, 3 September 2018 (September 3, 2018).

. "Virtual or Virtueless? The Evolution of Money in the Digital Age." In Lecture at the Official Monetary and Financial Institutions Forum, London, 8 February 2018.

. "Why Europe Still Needs Cash." Contribution by Yves Mersch, Member of the Executive Board of the ECB for Project Syndicate (28 April 2017).

Nabilou, Hossein, and Alessio Pacces. "The Law and Economics of Shadow Banking." Chap. 1 In Research Handbook on Shadow Banking: Legal and Regulatory Aspects, edited by Iris H. Chiu and Iain G. MacNeil, 7-46. Cheltenham, UK: Edward Elgar Publishing Inc., 2018.

Nabilou, Hossein, and André Prüm. "Central Banks and Regulation of Cryptocurrencies." (2019).

- "Ignorance, Debt and Cryptocurrencies: The Old and the New in the Law and Economics of Concurrent Currencies." Journal of Financial Regulation (forthcoming) (2018).

Nakamoto, Satoshi. "Bitcoin: A Peer-to-Peer Electronic Cash System." 2008.

Narayanan, Arvind, and Jeremy Clark. "Bitcoin's Academic Pedigree." Communications of the ACM 60, no. 12 (2017): 36-45.

Poon, Joseph, and Thaddeus Dryja. "The Bitcoin Lightning Network: Scalable Off-Chain Instant Payments." (2016).

Pozsar, Zoltan. "Shadow Banking: The Money View." Office of Financial Research Working Paper (July 02, 2014 2014).

Prasad, Eswar. "Central Banking in a Digital Age: Stock-Taking and Preliminary Thoughts." Hutchins Center on Fiscal \& Monetary Policy at Brookings (April 2018).

Prasad, Eswar S. Gaining Currency: The Rise of the Renminbi. New York: Oxford University Press, 2017.

Proctor, Charles. Mann on the Legal Aspect of Money. 7 ed. Oxford: Oxford University Press, 2012.

Raskin, Max, and David Yermack. "Digital Currencies, Decentralized Ledgers, and the Future of Central Banking." National Bureau of Economic Research, 2016.

Research, BitMEX. "A Complete History of Bitcoin's Consensus Forks." (28 December 2017).

Ricks, Morgan. "Money as Infrastructure." Vanderbilt Law Research Paper No. 17-63 (2018).

Ricks, Morgan, John Crawford, and Lev Menand. "A Public Option for Bank Accounts (or Central Banking for All)." Vanderbilt Law Research Paper 18-33 (2018).

Riksbank, Sveriges. "The Riksbank's E-Krona Project Report 2." In E-krona reports. Stockholm: Sveriges Riksbank, October 2018.

"The Riksbank's E-Krona Project, Report 1." In E-krona reports. Stockholm: Sveriges Riksbank, September 2017.

Rogoff, Kenneth S. The Curse of Cash. Princeton: Princeton University Press, 2016.

Sanches, Daniel R. "Bitcoin Vs. The Buck: Is Currency Competition a Good Thing?". Federal Reserve Bank of Philadelphia Economic Insights Q2 2018 (2018): 9-14.

Selgin, George. "Synthetic Commodity Money." Journal of Financial Stability 17 (2015/04/01/ 2015): 92-99.

Selgin, George A. Good Money: Birmingham Button Makers, the Royal Mint, and the Beginnings of Modern Coinage, 1775-1821. University of Michigan Press, 2011.

Siekmann, Helmut. "Exit, Exclusion, and Parallel Currencies in the Euro Area." Institute for Monetary and Financial Stability Working Paper Series No. 99 (2015) (2015).

Szabo, Nick. "Money, Blockchains, and Social Scalability." Unenumerated (February 09, 2017).

Weber, Warren E. "Government and Private E-Money-Like Systems: Federal Reserve Notes and National Bank Notes." Bank of Canada Working Paper 2015-18 (2015). 
White, Larry. "The World's First Central Bank Electronic Money Has Come - and Gone: Ecuador, 20142018." Alt-M: Ideas for an Alternative Monetary Future (March 29, 2018).

White, Lawrence H. "Competing Money Supplies." The Library of Economics and Liberty (2018).

Wirdum, Aaron van. "The Genesis Files: How David Chaum's Ecash Spawned a Cypherpunk Dream." Bitcoin Magazine (24 April 2018).

—. "The Genesis Files: If Bitcoin Had a First Draft, Wei Dai's B-Money Was It." Bitcoin Magazine (15 June 2018).

—. "The Genesis Files: Hashcash or How Adam Back Designed Bitcoin’s Motor Block." Bitcoin Magazine (4 June 2018).

"A Primer on Bitcoin Governance, or Why Developers Aren't in Charge of the Protocol." BITCOINMAGAZINE, Sept. 7, 2016.

Wolman, David. The End of Money: Counterfeiters, Preachers, Techies, Dreamers--and the Coming Cashless Society. Boston, MA: Da Capo Press, 2012.

Yeoh, Peter. "Regulatory Issues in Blockchain Technology." Journal of Financial Regulation and Compliance 25, no. 2 (2017): 196-208. 